\title{
TAXONOMIA MÍTICA: UNA NUEVA FORMA DE ENCARAR LOS RELATOS
}

\begin{abstract}
RESUMEN
En este trabajo, la autora presenta una clasificación de los mitos en ocho categorías según el tema al que hagan referencia, la cual favorece el ordenamiento de las narraciones míticas.
\end{abstract}

Kattia Chinchilla Sánchez

\section{ABSTRACT}

In this paper, the author presents a division of myths into eight categories, depending on he topic they deal with. This classification is useful for organizing mythic narrations.

El país que no tenga leyendas está condenado a morir de frío. Es muy posible. Pero el pueblo que no tenga mitos está ya muerto.

G. Dumezil

A pesar de su diversidad temática, los mitos pueden ser clasificados o tipificados en ocho categorías. No obstante, hay que aclarar un aspecto: un relato mítico es capaz de albergar una u otra clase, de acuerdo con su extensión o de acuerdo con su tópico específico. Por tanto, la taxonomía que presentaremos no es excluyente ni definitiva; es una opción viable para ordenar las narraciones con base en su contenido.

\section{Mitos cosmogónicos}

Los mitos cosmogónicos son aquellos que narran el origen del universo, el origen del cosmos, el origen del mundo. En la primera parte del Popol Vuh, por ejemplo, los maya-quiché difundieron una historia cosmogónica, en la cual impera el silencio de la inmensidad:

Esta es la relación de cómo todo estaba en suspenso, todo en calma, en silencio; todo inmóvil, callado, y vacía la extensión del cielo (Popol Vuh 1979: 25).

El desencadenamiento de las fuerzas de la naturaleza se da en forma de neblina, la cual inicia la vida.

Sólo el Creador, el Formador, Tepeu Gucumatz, los progenitores, estaban en el agua rodeados de claridad (Popol Vuh 1979: 25). 
El párrafo anterior ha suscitado comentarios variados en cuanto a la esencia de los seres míticos allí citados. Primero, tanto Tepeu como Gucumatz reciben un tratamiento en singular y en plural; esto no obedece a una incongruencia gramatical, sino a una conceptualización binaria o dual, propia de la cultura maya y común en las manifestaciones hierofánicas (recuérdese el concepto de coincidentia oppositorum). Además, el hecho de que los Progenitores estuviesen inmersos en el agua y rodeados de claridad implica su tautegoría (ser en sí mismo) y su contacto con elementos capaces de cosmificar la materia: el agua y la luz. Uno es líquido, Gucumatz, y el otro, la luz, Tepeu.

Agua, sol, tierra y aire son los soportes tradicionales de la existencia:

Luego la tierra fue creada por ellos. Así fue en verdad como se hizo la creación de la tierra: -

¡Tierra!, dijeron, y al instante fue hecha.

Como la neblina, como la nube y como una polvareda fue la creación, cuando surgieron del agua las montañas; y al instante crecieron las montañas (Popol Vuh 1979: 26).

Promulgado el divino mandato, queda hecho el cosmos y sus componentes: el sol y el agua en su conjunto; obran la tierra y, al mismo tiempo, su atmósfera. La liberación de las fuerzas conduce a la ingente polvareda, la extensa nebulosa, de la cual se desprenden los astros que llenarían el firmamento.

Los aztecas, por su parte, aseveran que el cosmos fue obra de Quetzalcóatl, deidad cosmogónica única en este proceso. Sin embargo, ciertas versiones narran lo siguiente: Quetzalcóatl y Tezcatlipoca bajaron, desde el cielo, a la diosa tierra, quien tenía sus articulaciones llenas de ojos y bocas, con aspecto de bestia salvaje. Anteriormente, había agua — de la cual nadie conocía el origen- sobre la que la diosa empezó a caminar.

Al ver esto, las divinidades citadas crearon la tierra: se convirtieron en serpientes y tomaron a la diosa; uno de ellos, por la mano derecha y el pie izquierdo, y el otro, por la mano izquierda y el pie derecho. Presionaron de tal forma que la rompieron por la mitad. De la parte trasera de los hombros, hicieron la tierra y, de la restante, crearon la esfera celeste.

En apariencia, la diosa de la tierra luce como un sapo, capaz de devorar el universo. Empero, este batracio, al igual que la rana, se vincula de manera decidida tanto con la creación como con la fertilidad, amén de su naturaleza anfibia (agua y tierra). A causa de ello, la entidad sapo-diosa de la tierra contiene en sí misma lo celeste-acuático y lo telúrico-ctónico, visión cosmificadora particularizada en esas dos mitades que son luego escindidas.

Asimismo, los aztecas poseían una noción periódico-cíclica del universo: el mito de los cinco soles. Esta cosmovisión predomina en las culturas mexicanas, centroamericanas y hasta peruanas. Como dato curioso, Seler anotaba que los cuatro primeros estadios correspondían al ancestral concepto occidental de los cuatro elementos: agua, tierra, fuego y aire. El primer sol, bajo el signo de "cuatro atl" (cuatro-agua), se llama Atonatiuh (sol de agua). Aconteció que todo fue absorbido por las aguas y las personas se transmutaron en peces. El agua contiene tanto matices germinativos como destructivos: es fons et origo, fuente y origen, de toda existencia, pero capaz de anegar, inundar y extinguir las formas de vida. Este sol tuvo una duración de 676 años y el dios supremo era Tezcatlipoca.

Al segundo sol, bajo el signo "cuatro ocelotl" (cuatro-tigre), se le nomina Ocelotonatiuh (sol de tigre). Durante este ciclo, el cielo se hundió. Además, el sol no "caminaba" desde 
donde se ubica el medio día y luego se oscurecía todo en derredor. Habiendo imperado las tinieblas, la gente fue devorada y, a partir de lo acontecido, hubo una práctica coloquial común. Consistía en saludar con la cláusula: "que no caiga usted", pues el que caía, lo hacía para siempre. Este sol duró 364 años, bajo la tutela de Quetzalcóatl. En relación con las implicaciones simbólicas del tigre o jaguar en mención, podemos afirmar que es el animal devorador por antonomasia: se comía el sol durante un eclipse total o parcial. Era un demonio de la oscuridad y las manchas de su piel son las estrellas del cielo. De ahí su ligamen con la ausencia de luz de la dimensión telúrica (el inframundo, el estrato ctónico).

Al tercer sol, bajo el signo "cuatro quiauhuit" (cuatro-lluvia) se le advoca Quiauhtonatiuh (sol de lluvia). En tal lapso, llovió fuego y todo ardió en el acto. Además, se precipitaron piedras, las cuales son las que vemos actualmente; entre ellas puede citarse el tezontle, una roca liviana llena de agujeros. El fuego posee un carácter detersivo innato: destructor, purificador y generador. Por otro lado, los hombres de este período fueron convertidos en pájaros, mariposas y perros, animales que por lo general se asocian con el fuego celeste y terrenal. Este sol tuvo una duración de 312 años, bajo la rectoría de Tláloc.

El cuarto sol, bajo el signo "cuatro ehécatl" (cuatro-ciento) fue Ehecatonatiuh (sol de viento). Todo fue arrasado por el viento y la gente se transformó en monos, esparcidos por el bosque. El viento implica no sólo lo celeste sino también el hálito fecundador; no obstante, sus calidades destructivas son inherentes. Este ciclo duró 676 años y fue dedicado a Chalchihuitlicue, esposa de Tláloc.

El quinto y último sol es el "actual”, pues el mito azteca así lo configuró. Se ubica bajo el signo "cuatro-ollin” (cuatro-movimiento), pues se movió "caminando”. Según los mayores, habrá terremotos y hambre por doquier, por lo que hemos de perecer. Este período tuvo origen en el año 726 de la edad cristiana y su fin se esperaría para el año 2195.

Los bribris, por su parte, son poseedores de un curioso relato cosmogónico: la tierra era pura roca, piedra desnuda, carente de vida; entre tanto, Pikiru, el Gran Murciélago, se internó en el inframundo y allí se encontró con Iriria, la Niña Tierra, quien estaba dormida y sin nacer; no obstante, le hacía compañía la Gran Abuela. Pikiru voló hacia el exterior y, de sus deyecciones, las rocas comenzaron a cubrirse y rodearse de musgo, hierba, incluso árboles. Sibú, el Hacedor, estaba estupefacto ante los acontecimientos e inquirió directamente al Gran Murciélago sobre su medio de alimentación. Pese a sus primeras negativas, Pikiru al final confesó que había una niña, quien duerme bajo las rocas, a la cual le extrae sangre de sus dedos. Sibú ordenó la presencia inmediata de Iriria, la Niña Tierra. Nadie pudo con la tarea, ni el Gran Murciélago, ni el Dueño del Puercoespín, ni la Dueña del Tigre. No pudieron romper la roca y, con ello, traerla al mundo exterior. Aún Kerma, el Trueno, mediante grandes retumbos, no logró sacar a la Niña Tierra, quien pesaba demasiado. Sólo fue posible llevar a cabo la misión con el concurso de la Gran Abuela: tras un fortísimo estruendo, subió a la Niña Tierra en brazos y la colocó en el suelo. Sibú convocó a una fiesta de danza y de música. La Gran Abuela estaba presta para recibir a la Niña Iriria, con tan mala fortuna que, untada de manteca de cacao, resbaló y recibió un golpe mortal. La Gran Abuela lloró desconsoladamente y de sus lágrimas surgieron los tigres, las águilas, los ríos, los lagos, el cacao, la avispa, el mosquito y la hormiga negra. Entre tanto, los danzantes pasaban por encima del cuerpo inerte de Iriria, hasta convertirla en polvo, del cual surgió el maíz, la yuca, la palma y los árboles frutales. 
Del relato podemos deducir la cadena cosmogónica propicia para la generación de la vida: SANGRE-DEYECCIONES-LÁGRIMAS. Sus dones germinativos devienen del agua, es decir, éstas son manifestaciones simbólicas, las cuales sugieren que el líquido vital es parte constitutiva del cosmos. Asimismo, tanto la Gran Abuela como Iriria, la Niña Tierra son evidentes motivos telúricos, o sea, de la tierra. En suma, una conjunción particular y efectiva de tierra y agua sustenta la cosmogonía bribri, mientras que, de manera opuesta, según la tradición judeocristiana, fue la separación de tales elementos esencial para la creación del mundo. No obstante, la reunión de agua y tierra fue la materia prima para la creación del hombre, como reza en la Biblia.

\section{Mitos cosmológicos}

Estos mitos cuentan el origen del cosmos, pero ese saber es elitista y sectario. En otras palabras, es un mito cosmogónico que sólo se maneja en un nivel de grupo cerrado, no está al alcance de la colectividad. Buen ejemplo de estas historias es el relato de los órficos, una cofradía mistérica griega de la Antigüedad. Orfeo sería el iniciador de los misterios que llevan su nombre. Empero, su génesis cultual está ligada intrínsecamente con los rituales dionisíacos: contábase que había sido descuartizado por unas furibundas ménades, partícipes de las bacanales, quienes lo habían confundido con el macho cabrío del sacrificio. Situación similar atravesó el célebre Penteo, motivo central de la tragedia Las Bacantes de Eurípides. Antes del mortal desconcierto, Orfeo se había casado con Eurídice. Todo transcurría apaciblemente hasta que encuentra la muerte, al ser mordida por una serpiente venenosa. Orfeo, músico sublime, no soportó el dolor de la pérdida y decidió descender él mismo al Hades, en procura de su mujer. Astutamente, duerme al can Cerbero con las dulces notas de su lira y así se encuentra cara a cara con el temible Hades, rector del inframundo. Luego de una larga discusión, el rey de los muertos accede a que Orfeo se lleve a Eurídice al mundo de los vivos, pero le impone una condición: la fémina iría siguiendo a Orfeo y éste por ningún motivo debía mirar hacia atrás. Así se acordó y pronto emprendieron el trayecto a casa. Sin embargo, la duda carcomía a Orfeo, quien dudaba de la palabra de Hades: ¿vendría Eurídice detrás de él o habría sido objeto de la más infame de las burlas? Traicionándose a sí mismo, giró su cabeza de inmediato, sólo para contemplar cómo su amada era devuelta a la zona de los muertos por una fuerza poderosa e invisible. Lo sustancial aquí es cómo Orfeo logra penetrar a un mundo vedado, tabuado por la ley de la vida y logra salir de allí sin tacha física alguna, no obstante, con el irreparable dolor de la doble pérdida de su esposa Eurídice. Obviamente, la idea de la transmigración de las almas era base del culto órfico.

Toda clase de arcanos rodean el pensamiento de este grupo mistérico, hasta su famosa contraseña: "macho cabrío, caí en la leche". La fórmula no invita a suponer un baño ritual de leche para la purificación del mystes; más bien, sugiere que el iniciado, macho cabrío místico, identificado con la víctima y con el dios del misterio, ha encontrado la felicidad, la garantía de la salvación eterna.

Según los órficos, el principio de todas las cosas era Cronos, junto con el cual existía desde siempre la ley fatal de la necesidad (Adrasteia). De Cronos nacieron Eter, Caos y Erebos. 
Cronos formó en el Eter un huevo brillante como la plata y de éste nació Phanes (el que brilla), el Protógonos de los dioses. De Phanes procede su hija, la Noche, y de la unión entre ambos surgen la Tierra (Gaia) y el Cielo (Ouranos). Del ayuntamiento de estos dos últimos nacieron la siempre mortífera Equidna y las Moiras (Cloto, Láquesis y Atropos). Por tanto, Phanes es considerado el hacedor del universo y, además, era andrógino, es decir, contenía los dos opuestos genéricos. Otras versiones indican que hubo un huevo primitivo, se partió en dos mitades, de las cuales emergen el Cielo y Tierra.

Una tradición órfica aislada señala que en un principio existía un caos formado con base en el agua y el fango (hyle: materia). Esta mixtura se endureció para constituir la tierra. De ahí, brotó un dios serpiente con alas y con tres cabezas: de dios, de toro y de león. Su nombre era Cronos, quien existía junto con la necesidad (Ananké), la cual domina sobre todo el cosmos. Cronos engendró de sí mismo al Eter, al Caos, al Erebos y a un huevo, del cual nació el Protógonos, quien tenía cabeza de toro, rematada por una serpiente con alas de oro. Aflora Zeus, el ordenador de todas las cosas, Pan y un globo de cristal, que, al escindirse en dos mitades, genera el cielo y la tierra.

De lo anterior, podemos inferir lo siguiente: los órficos poseían la firme convicción de que hubo un Protógonos o primigenio entre los dioses, llamado Phanes, creador de todo lo existente y de la estirpe de Cronos. Por otra parte, hubo un huevo, o en su defecto un globo de cristal, que al separarse da origen a la esfera celeste y al dominio terráqueo. El huevo está ligado con la génesis del universo, pues es semilla de la multiplicidad de los gérmenes. Sus rasgos sexuales se visualizan en el amarillo (humedad femenina) y en el blanco (el esperma masculino); en términos cosmobiológicos, la tierra es generalmente femenina y el cielo es generalmente masculino. Encierra la fecundidad en sí misma y, por ende, la capacidad de engendrar el universo entero.

Grecia dio a luz una élite mistérica muy singular, jefeada por Pitágoras de Samos (nacido probablemente en el 580 a.C.), cuyo eje de pensamiento era el orden cósmico impuesto por el número y sus infinitas combinaciones. Se atribuye a Pitágoras la introducción del nombre "filósofo", mas su sentido primario de "amar a la sabiduría" adquirió un valor religioso, pues es considerado el medio y el camino adecuados para la purificación espiritual y para la salvación del alma (metempsícosis). De esta manera, los pitagóricos comparten con los órficos las ideas del alma y de una especie de pecado original, el cual debe ser expiado en la cárcel corpórea, al pasar de un cuerpo a otro en una serie de vidas (transmigración de las almas). Una vez que logre la purificación, el individuo es liberado del ciclo de los nacimientos. Según los órficos, tal redención se cumple a través de la iniciación religiosa y de la participación en los ritos sagrados. Para los pitagóricos, aquella se obtendría mediante el culto del saber. Dicho basamento se ve reflejado en un fragmento de Píndaro:

Pero aquellos que han pagado la expiación del antiguo pecado a Perséfone, ella envía su alma después de nueve años a la suprema luz del sol, para vivir como reyes ilustres, hombres de potente fuerza y superiores en sabiduría, y luego son llamados, por los hombres, para siempre, santos héroes (Píndaro, fragmento 133).

Así, la vida dedicada a la sabiduría es la vía de retorno del alma al estado divino (santos héroes), como se aprecia en estas citas extraídas de Platón:

Son sacerdotes y sacerdotisas que se han aplicado a dar razón de lo que concierne a su minis- 
terio. Es Píndaro y otros poetas; entiendo los verdaderamente divinos. Y es eso lo que dicen; examina si te parece justo.

Dicen que el alma humana es inmortal, y que tan pronto abandona la vida -lo que llaman morir-, muy luego a la vida vuelve sin que nunca se destruya; y, por tanto, conviene vivir lo más piadosamente que se pueda, porque las almas de aquellos que han pagado a Perséfone la deuda de sus antiguas faltas, son devueltas a la luz del sol, al cabo de nueve años. De estas almas se forman los reyes ilustres, los hombres poderosos por su fuerza o grandes por su saber, honrados luego como héroes intachables entre los mortales.

Así, el alma, inmortal y renaciendo muchas veces, habiendo contemplado todas las cosas, sobre la tierra y en la morada de Hades, nada hay que no haya aprendido (Platón, Menón: 81 ab).

La verdad es en realidad purificación de toda pasión; (...) y los que han establecido las iniciaciones no son hombres despreciables, sino genios que desde hace tiempo nos han hecho comprender que quien sin purificación y sin iniciación en los misterios llegare a la morada de Hades yacerá en el lodo; mas quien vaya purificado e iniciado morará con los dioses. Porque dicen los que presiden las iniciaciones- son muchos los que llevan el tirso, mas pocos los inspirados (Platón, Fedón: 69 d).

Pero los que parecen haber vivido mejor a causa de la santidad de su vida, son lo que se ven liberados y separados de estos lugares de la tierra como de prisiones, y llegan allá arriba a la morada pura, y son colocados allí como habitantes. De éstos, los que han sido suficientemente purificados por la filosofía viven por toda la eternidad separados de sus cuerpos y llegan a moradas más bellas todavía (Platón, Fedón: 114 c).

Entonces es cuando el alma está frente a la prueba y combate supremos. Las almas llamadas inmortales, cuando han subido a lo más encumbrado de los cielos, se elevan sobre la convexidad de la bóveda celeste, y las arrastra su movimiento circular mientras contemplan las realidades que están fuera del cielo (Platón, Fedro: 247 d).

Desde esta perspectiva, los purificados por la filosofía son liberados de la cárcel corpórea y vuelven a vivir el tiempo futuro en las regiones celestiales.

Habiendo tomado los principios de Anaximandro (ápeiron) y Anaxímenes (pneuma), Pitágoras postula que la realidad primordial es el pneuma ilimitado, el vacío (kenón) o el espacio. Dentro del pneuma ilimitado, agitado por el movimiento eterno, se formó un cosmos esférico, limitado, lleno y compacto. Este cosmos es el uno, la mónada, lo Impar, y constituye el principio de la unidad. Era una esfera viviente, dotada de respiración. Al hacerlo, en tiempos inmemoriales, inhaló el pneuma ilimitado y el vacío, los cuales penetraron en el interior y disgregaron su unidad. De esta manera, se origina la pluralidad numérica de las cosas, cada una de ellas es igual a una unidad o a un número.

La naturaleza estaba hecha a imagen de los números, los primeros en la naturaleza, constitutivos de todos los seres, de ahí que el universo entero es armonía y número. Los pitagóricos habían notado, en lo numérico, las determinaciones y las proporciones de las armonías, producto del descubrimiento personal del gran maestro, a partir de los acordes musicales de octava, de quinta y de cuarta: la correspondencia entre cada nota y la longitud de la cuerda vibrante, por lo que las variedades de los sonidos se hacían geométricamente mensurables ("música de las esferas"). Varrón atribuía el hallazgo a la observación de los intervalos armónicos en los sonidos de los martillos de un forjador sobre el yunque y, luego, hallóse que concernían a la diferencia de peso entre los martillos. El concepto de armonía musical se encuentra, por 
influjo del pitagorismo, en el pensamiento de Heráclito:

Los hombres ignoran que lo divergente está de acuerdo consigo mismo. Es una armonía de tensiones opuestas, como la del arco y la lira (Heráclito, fragmento 51).

Son uniones: lo entero y lo no entero, lo concorde y lo discorde, lo consonante y lo disonante, y del todo el uno del uno el todo (Heráclito, fragmento 10).

El sitial de honor del reino de los números puede ser apreciado incluso en la China milenaria, donde toda la clave de la armonía macro-microcósmica, de la conformidad del imperio con las leyes celestes, de la noción de los ritmos cósmicos están en relación directa con la ciencia numérica. De ahí, su alianza con la música y la arquitectura. Beocio, ya en Roma, aseguraba que el conocimiento supremo pasaba por los números y Nicolás de Cusa, en el Medioevo, opinaba que el número era el mejor vehículo para acercarse a las verdades divinas: todo está dispuesto según su exacto designio.

Para algunas culturas, como la peul (pueblo africano de origen beréber, establecido en Guinea y Malí), no conviene utilizarlos con propósitos erróneos, pues los números encierran una fuerza desconocida: es el resultado de la palabra y del signo, más esencial y más misterioso que sus componentes. Así, no se debe revelar la edad, la cantidad de hijos, mujeres, bueyes y demás posesiones, ya que al ser enunciados — sea un nombre o un número- desplazan las fuerzas invisibles, pero presentes, como arroyos subterráneos. Si, desde esta óptica, la palabra es la explicación del signo, el número es efectivamente la raíz críptica.

La periodicidad residente en unidades numerables de los ciclos cósmicos pudo haber sugerido la idea de que los números no son meros auxiliares del orden introducidos por el hombre, sino cualidades primarias del universo, huellas absolutas de poderes sobrehumanos y, por ende, sacros símbolos de la deidad. Novalis (1993: 327), poeta alemán, experimentó tal poder mágico-numérico por medio de su incursión en la mística:

Es muy probable que en la naturaleza exista una maravillosa mística de los números; también en la historia. ¿Acaso todo lo importante no es simetría y relación? ¿No puede Dios revelarse en la matemática como en cualquier otra ciencia? (En Biederman: 327).

Según el criterio pitagórico, sin el número todas las entidades serían ilimitadas, inciertas y oscuras, pues la naturaleza numérica es ley, guía y maestra de cada cosa dudosa e ignota. Nótese que se le están confiriendo, al número, categorías cosmificadoras y cosmogónicas, sea ordenadoras. De los diez primeros dígitos ordinales, tres tienen una relevancia capital: el uno, el tres y el diez. La mónada o el uno es el principio de todo; sin embargo, el todo y todas las cosas están determinados en tres dimensiones: el principio, el medio y el fin (trinidad o tríada). El número completo es el diez, la suma de los cuatro primeros $(1+2+3+4$ : tetractis o número cuaternario). La eficacia y la esencia del número, en la Década, son grandes, perfectas, omnipotentes y divinas. Puesto que la Década albergaría el estado de perfección, en las vidas celeste y humana, los pitagóricos afirmaban que son diez los cuerpos del cielo en movimiento: nueve son visibles y uno invisible — la antitierra-, el cual completa la suma exacta (ver Aristóteles, Metafísica: I, 5, 985).

Por otro lado, las sectas, como la Masonería, comprenden una visión cosmológica, a 
pesar de la constante negación de un vínculo mítico-religioso por parte de sus adeptos. Por ejemplo, la iniciación hermético-alquímica está presente por igual en los tres grados masónicos de aprendiz, compañero y maestro, los cuales reproducen las tres etapas de la "Gran Obra", las que incluyen una muerte, un renacimiento y una resurrección. Las leyes herméticas de las correspondencias y analogías entre el macro y el microcosmos están resumidas y sintetizadas en el esquema general del templo o Logia masónica, verdadera imagen simbólica del mundo. La aritmética es sagrada en la simbólica de los números en su vertiente cosmológica y metafísica. Aquí se observa, con mayor claridad, el influjo del pitagorismo en la Masonería. Ambas tradiciones ponen el acento en el sentido cualitativo de los números, de por sí vinculado estrechamente con en el simbolismo geométrico, el que, a su vez, está relacionado con la construcción del templo exterior y del templo interior. Contábase que, en el frontón de la Academia de Atenas, Platón hizo grabar una inscripción que rezaba: "Nadie entre aquí que no sepa geometría" ("Meedeis areoometreetos eisitoo moy teen stegeen"), claúsula atribuida a los pitagóricos que bien podría estar escrita en el pórtico de una Logia.

El legado de la cosmogonía grecorromana unida a la espiritualidad cristiana, dio como resultado la creación de la catedral gótica, edificada por los gremios de constructores. Una catedral, o un monasterio, es un compendio de sabiduría; en ella, grabada en piedra, se plasman los diferentes episodios bíblicos que conforman la historia de la tradición judeocristiana. Allí aparecen los diversos reinos de la naturaleza — según su criterio, eran el mineral, el vegetal, el animal y el humano- lo mismo que las jerarquías angélicas que circundan en el libro de imágenes y símbolos herméticos reveladores de la estructuras sutil y espiritual del cosmos. Ahora bien, el nexo de esto con la masonería se remonta a su génesis: el grupo de albañiles que levantaron la catedral de Edimburgo durante los siglos XIV y XV. De ahí que la secta en cuestión conciba el cosmos como una obra arquitectónica y a la divinidad como un Artesano o Gran Arquitecto del Universo, también llamado Espíritu de la Construcción Universal.

Así las cosas, el mundo fue creado a hechura de un templo/catedral, resumen del macrocosmos y que es también la imagen del microcosmos (mundo y hombre). Todo allí se halla ordenado, amén de la cohesión que realiza el eje del mundo (axis mundi), que concatena las tres regiones cósmicas: cielo, tierra e infierno. El techo (cabeza) es el cielo, las columnas, las paredes y el piso (tronco) son la tierra y, por último, las bases (pies) son el inframundo, la zona ctónica.

De acuerdo con los registros ancestrales, los orígenes de la fraternidad masónica datan desde la construcción del Templo de Salomón, como lo estipula la Biblia: 60 codos de largo, 20 de ancho y 30 de altura (cada codo mediría en la actualidad 42 centímetros aproximadamente). El pórtico delante del templo tenía 20 codos de longitud —en el sentido de anchura del templo- y 10 codos de anchura —en el sentido de longitud del mismo (1 Re 6,3). El santuario fue diseñado para situar en él el arca de la alianza. El interior del santuario, de forma cúbica, poseía 20 codos de longitud, 20 codos de anchura y 20 codos de altura $(1 \operatorname{Re} 6,20)$. Allí, dos querubines de madera de acebuche medían 10 codos de altura y sus alas medían cada una 5 codos. La altura de cada querubín era igualmente de 10 codos y ellos se hallaban ala contra ala $(1 \operatorname{Re} 6,23)$.

En el Libro de los Reyes se pueden apreciar los prototipos de los grados de la Masonería, desde el propio Rey Salomón, hasta Hiram (rey de Tiro, quien brindó los materiales, sobre todo madera de cedro), Adoniram y otros. Algunos grados del ritual escocés datan de los 
períodos antiguos, como la dispersión de los hebreos (Libro de los Números), la mitología del antiguo Egipto, el lapso postdiluviano de los hijos de Noé. Conectados con el saber de los Misterios de la Antigüedad, los masones compartían con ellos los ritos iniciáticos y la transmisión de secretas enseñanzas, en primera instancia arcanos del arte de la construcción.

Generalmente, se ha aceptado la génesis de esta cofradía a partir de los gremios de albañiles de la Edad Media. El término "libre" ("free") en la palabra Fracmasonería indica que ellos no estaban supeditados a un territorio en particular, sino que viajaban libremente a través del país que fuere y, por ende, se les requería en cualquier parte para las edificaciones de gran envergadura, en especial las grandes catedrales. Así, se nutrieron de los principios de la geometría, de la aritmética y de la ingeniería, y el gremio de albañiles y arquitectos cultivó sus enseñanzas de generación en generación, alrededor de la secta, cofradía, hermandad o Logia. El período moderno de la Masonería data de la fundación de la Gran Logia el día de San Juan en 1717, en Londres. Aglutinaba a todos los libres pensadores de Occidente. De aquí, el movimiento se expandió a otras naciones europeas y luego al territorio americano.

La Masonería en sí misma es un ideal de vida — dicen sus cofrades_, con base en el amor a la humanidad mediante la iniciación y el orden cósmico generado por el Gran Arquitecto. Su utopía es la búsqueda de un mundo mejor gracias a una sociedad fraternal. La Masonería alberga el viejo arquetipo de la lucha de los hijos de la luz contra los hijos de la oscuridad, plasmada siglos atrás en los mismos textos de Qumram (rollos del Mar Muerto). La respuesta masona a la violencia sin sentido es el diálogo; la respuesta masona a la guerra es la paz. Supónese inclusive que el lema libertad, igualdad y fraternidad y sus implicaciones en la Revolución Francesa y, por añadidura, en la redacción de todas las constituciones republicanas ulteriores, fueron producto de la Masonería y del Gran Libro de la Arquitectura: libertad es la condición básica del hombre (eje de toda sociedad), igualdad es el ideal ante los ojos de la ley y fraternidad es la esencia para el mutuo entendimiento entre los hombres.

\section{Mitos etiológicos}

Los mitos etiológicos se refieren a la causa generadora de una manifestación concreta de la sacralidad (hierofanía). Narran el origen de una particularidad mítica: un monte, una planta, una piedra, un volcán, un árbol y demás, que por su aspecto peculiar sale del ámbito de lo cotidiano.

Al sureste de la ciudad de México, a unos 80 kilómetros de distancia, se elevan un par de volcanes: el Iztaccihuatl y el Popocatépetl. El primero tiene la forma de una mujer dormida boca arriba y el segundo parece su vigía, quien de rodillas cuida su eterno sueño. Contábase que Popocatépetl era un famoso guerrero indígena y su novia era la bellísima princesa Iztaccihuatl. Un día el joven guerrero debió marchar al combate, ella le hizo un juramento de amor: le colgó del cuello una calabacita con agua y miel. Tal era la promesa de esperarlo el tiempo necesario para casarse con él. Mientras Popocatépetl luchaba lejos, un temido guerrero rival incursionó hasta el palenque de Iztaccihuatl y disparóle a la princesa una flecha mortal. Popocatépetl volvió alegre y victorioso, sólo para hallar a su amada muerta sobre un lecho de maguey. Desesperado, el valiente luchador formó con sus manos una enorme montaña y en su cumbre colocó a la princesa inerte. Después se hincó a su lado, para velar, durante toda la 
eternidad, el sueño de su amada. De ahí, la forma particular de ambos volcanes que llevan el nombre de estos personajes.

Los bribis se refieren al origen del achiote mediante la historia de la rana de achiote o Kchabuká. Según ellos, el color rojo sirve para oficios de purificación, para librarse del mal. Sibú hizo a Kchabuká roja, pequeña, con patitas negras. Es tan antigua como la tierra, pues existió desde el principio. La ranita vivía feliz bajo su árbol, cazando gusanos y otros animales pequeños. Sucedió que Sibú no quería prestarle su bastón a la Mujer Mar, porque ella era peligrosa. Sin embargo, accedió a dárselo, pero el bastón se transfiguró en serpiente y la mordió mortalmente en la mano. La colocaron debajo de un túmulo para enterrarla. No obstante, el estómago de la Mujer Mar crecía sin remedio, por lo que el túmulo se iba levantando. Entonces Sibú llamó a Kchabuká y le ordenó subir al túmulo y detener su crecimiento al colocarse en la cumbre. Allí se posó, pero la tierra seguía estremeciéndose. Pasaron varios días y el hambre se apoderaba de la pequeña rana, mas al ver un gusano, fue tras él. Después, cuando quiso retornar a su sitio, hubo un gran estallido y, con ello, un terrible terremoto. Se abrió la tierra y brotó el Árbol Mar. Entre tanto, la rana fue expulsada de allí con gran fuerza. Sibú se dio cuenta de que Kchabuká había abandonado su puesto para ir a comer. Así, el Hacedor la colocó en un árbol como castigo; permaneció quieta como una bolita roja con espinas negras y suaves. El árbol en cuestión se convirtió, desde entonces, en el árbol de achiote y Kchabuká, la rana de achiote, es su fruto.

En Grecia está el Monte Sípilo y su génesis es como sigue. Níobe era una mujer muy vanidosa e impía, ya que se burlaba de la diosa Leto, madre de Artemisa y Apolo, a causa de su escasa fecundidad, pues la deidad sólo logró dar a luz a los gemelos arqueros, Artemisa y Apolo, con mucha dificultad. Níobe, por su parte, se jactaba de su abundante fertilidad: había parido siete hijos y siete hijas. Leto no soportó más las infames sátiras de la fatua mujer y urdió un plan de venganza en su contra: sus hijos divinos asesinarían, con sus mortales saetas, a los hijos de Níobe. Así lo hicieron, para desagraviar el honor mancillado de su madre. Las flechas de Artemisa liquidaban a las mujeres y las de Apolo a los varones. Ante la contemplación de tal horror, Níobe se retractaba, entre sollozos, por el ultraje cometido; sin embargo, su llanto pudo más y se metamorfoseó en monte, en el Monte Sípilo, el monte que llora, pues en él existe un ojo de agua, que vierte el líquido vital cual lágrimas de madre sufriente. Cabe destacar que en todos los mitos etiológicos el volcán, el árbol o el monte no son "representación" o "alegoría" de alguien o de algo, sino que son la cosa misma: Iztaccihuatl ES la mujer dormida, Kchabuká ES el achiote, Níobe ES el Monte Sípilo. Obviamente este principio es aplicable a todos los mitos de igual condición.

\section{Mitos teogónicos}

Los mitos teogónicos reseñan el nacimiento de los dioses. Grecia ofrece singulares ejemplos de este tipo de narración. En el período de los Titanes, al castrar Cronos a su padre Uranos, aquél lanza los órganos genitales al océano, que, al combinarse con la esperma, la sangre y la espuma marina, da como resultado a la diosa Afrodita, quien es recibida en la playa por las Horas. 
Por otra parte, el origen de Diónisos es muy particular. En la época de los Olímpicos, Zeus visitaba, en calidad de amante, a la Semele, mujer mortal. Hera, esposa de Zeus, al enterarse de la infidelidad de su marido, se transforma en anciana y se dirige a la casa de Semele, con el afán de sembrar la duda en ella, pues le cuenta que su amante no es sincero y que oculta su verdadera identidad. La joven cae en el ardid y, cuando Zeus llega, Semele le exige revelarse tal como es. El dios se niega, mas ante la insistencia de su amada, se manifiesta con poderosos rayos, los cuales pulverizan a la mujer. Sin embargo, Zeus logra extraerle del seno el fruto de sus amoríos, pero para completar su gestación, el padre de los dioses lo inserta en su muslo hasta que llegue el tiempo del alumbramiento. Es así como Diónisos nace dos veces: del seno de Semele y del muslo de Zeus; la etimología de su nombre parece indicarlo así: "nacido por dos puertas" ("nacido dos veces").

Otro ejemplo es éste. Zeus mantenía relaciones amorosas con Metis. Gea y Uranos le habían pronosticado que un hijo de ella sería capaz de destronarlo. Así las cosas, Zeus tomó la decisión de engullir a Metis, quien estaba grávida. Pasaron los meses, al cabo de los cuales, le sobrevino una fortísima jaqueca a Zeus, quien le pidió a su hijo Hefesto que le partiera la cabeza para ver el origen del dolor. El herrero de los dioses lo hizo, a la orilla del río Tritón, según el mandato de su padre y de la herida brotó Atenea, profiriendo gritos de guerra. De esta manera, del cerebro de Zeus, nace la diosa de la sabiduría, de la prudencia, de las artes marciales, del tejido y de los ardides.

\section{Mitos androgónicos}

Los mitos andrónicos se ocupan de contar cómo aconteció la creación del hombre. Los maya-quichés afirmaban que hubo modelos anteriores e inservibles, hasta llegar al arquetipo perfecto. Primero, los Progenitores modelaron al hombre de barro (agua y tierra), pero observaron que era demasiado blando, carecía de fuerza, estaba ciego y poseía otros defectos más. Deshicieron su obra. Optaron por un hombre de madera, mas vieron que no tenía alma ni entendimiento. Habiendo visto los fracasos precedentes, decidieron hacer al hombre con base en el maíz (mazorcas amarillas y blancas); su perfección, su buena presencia, su color, su sabiduría complacían a los Progenitores.

Una variante curiosa e interesante del hombre de maíz se encuentra en la cultura cackchiquel. Los primeros hombres se modelaron con base en la tierra, sin embargo, no poseían carne, ni sangre, ni podían caminar. Había dos animales que sabían que el maíz se hallaba en un lugar llamado Paxil: el coyote y el cuervo. Encontróse el preciado maíz en su excremento. El creador mató al coyote, le abrió los intestinos y le extrajo el dichoso grano. Con la ayuda de un colibrí se amasó, añadiéndole sangre de la serpiente de tapir. Así fue formada la carne del hombre por parte del creador. Este mito se asocia con la generación del hombre bribri, producto de la semilla del maíz y del excremento del Gran Murciélago Pikiru, quien se había alimentado con la sangre de Iriria, la Niña Tierra. En Babilonia, Marduk modeló al hombre con arcilla, hecha del cuerpo de Tiamat y la sangre del archidemonio Kingu.

Nótese que la materia prima se liga siempre a un elemento telúrico (tierra-maíz) y a su contraparte acuático-celeste (agua-sangre-excremento). La cadena de medios acuáticos se relaciona con lo celeste, en virtud de sus poderes germinativos y fecundadores, como lo es el 
nexo simbólico semen virile-lluvia. En suma, el hombre es la perfecta conjunción de la hierogamia cielo-tierra.

\section{Mitos soteriológicos}

Los mitos soteriológicos se refieren a los quehaceres de aquellos llamados o considerados "salvadores" de la humanidad. Sin duda, Jesucristo es uno de ellos, pero nos centraremos en tres figuras del mismo renombre: Mitra, Buda y Mahoma. El mitraísmo o los Misterios de Mitra llegaron a tener tanto peso como el cristianismo; inclusive la mayoría de mitraicos se plegó a la incipiente religión cristiana. Su culto se remonta hasta los orígenes mismos del pueblo indoiranio. En el antiguo panteón védico, como en la religión medo-persa y del Avesta, Mitra tiene su lugar, junto con Varuna y Ahura Mazda, dios de la luz y la verdad. Perdió aceptación en la India, mas acrecentó su popularidad en Persia. En la religión preavéstica, ocupa la posición de mediador entre el mundo superior y luminoso, donde impera Ahura Mazda (Ormuz) y en el mundo inferior, donde ejerce su dominio funesto Angro Mainyon (Ahrimán). La reyecía honra especialmente a Mitra como el dispensador de la gloria real, lo toman como testimonio de sus juramentos y lo invocan en los combates. Ormuz es la deidad suprema, pero Mitra era el objeto de la religión, porque era el héroe divino, realizador de la salvación. Debemos recordar en todo momento que el mitraísmo es un culto mistérico, por lo cual es obvio y natural el desconocimiento actual acerca de las particularidades del culto y el dogma. No obstante, todo pareciera estar basado en el episodio del encuentro entre el dios y el toro primordial, el bovino inmolado primario, del cual surgieron las plantas. Su simiente fue recogida y purificada por la luna y dio nacimiento a las especies de animales útiles; su alma, elevada hasta los dioses, se había convertido en genio protector del ganado. Este es el toro al que Mitra mató. Tal sacrificio, ubicado en el origen de la vida, garantiza la renovación perenne de la naturaleza. Anteriormente, se honraba a Mitra con el sacrificio del toro divino que, según la creencia avéstica, debe tener lugar al final de los tiempos por obra de Saoshiant: la grasa de este toro, mezclada con la savia del haoma blanco (árbol de la fuente de la vida), será un brebaje de inmortalidad para los elegidos, los iniciados en estos misterios. Así, Mitra había sido el creador y también era el salvador.

Los fieles de Mitra pasaban por una larga iniciación, la cual comprendía siete grados y cada uno de ellos tenía un nombre simbólico. Se ha supuesto una correspondencia entre las siete esferas planetarias que el alma tenía que atravesar para llegar a la morada de los bienaventurados. Los grados son: córax (cuervo), crypthius (oculto), miles (soldado), leo (león), perse (el persa), heliodromus (correo del sol) y pater (padre). Como en el cristianismo, los mitraicos creían que esta vida era el umbral de una vida eterna, la cual puede ser de felicidad o de dolor. En el último día, los muertos se alzarán de sus tumbas al llamado de Mitra: los bondadosos subirán a los cielos y los perversos serán arrojados al reino de las tinieblas (Mt 26,46; Jn 5,29; Jn 3, 18; Mt 18,8). Festejaban el nacimiento de Mitra el 25 de diciembre, fecha fijada luego para el nacimiento de Cristo en el siglo IV de nuestra era, y, además, guardaban el domingo. Puede afirmarse, sin temor a cometer mezquindad alguna, que los Misterios de Mitra llegaron a tener tanto peso como el cristianismo. Renán, por ejemplo, opina que si el cristianismo se hubiese detenido en su crecimiento, por algún imponderable, el mundo 
actual habría sido mitraista. Constituyeron el culto mistérico más firme en el ámbito occidental en el siglo III de nuestra era, mientras la propaganda cristiana llegaba a su culminación.

En Oriente, el budismo ostenta como su fundador a Siddhartha Gautama, llamado el Buda, que en sánscrito (Buddha) significa "el que ha despertado". Las cronologías de su nacimiento varían desde el 624 al 448 a. C. Su madre murió luego del alumbramiento, no sin haberse visto favorecida con todas las premoniciones que le anunciaban el nacimiento de un ser milagroso. Según las versiones docetas (doctrinas gnósticas) del nacimiento de Buda, su concepción y su gestación fueron inmaculadas y su nacimiento virginal. Su cuerpo había evidenciado todos los signos de un rey del mundo. A los 16 años se casó Siddhartha con dos princesas y empezó a llevar una vida disipada en el palacio paterno. Pero al salir del lugar, en tres ocasiones diferentes, conoció los tres males ineluctables que azotan a la humanidad: la vejez, el sufrimiento y la muerte. En su cuarta salida de palacio, Buda intuye cuál es el remedio, al contemplar la paz y la serenidad de un asceta que vive de limosnas. Cuando se despierta en medio de la noche, los cuerpos fláccidos de sus concubinas dormidas le revelan una vez más el carácter efímero del mundo. Abandona definitivamente la vivencia palaciega y se entrega a la vida ascética, cambiando su nombre a Gautama. Después de haberse alejado de sus dos maestros, que le habían enseñado respectivamente la filosofía y las técnicas del yoga, Buda practica un régimen de mortificaciones muy severas en compañía de cinco discípulos. Mas, habiendo comprendido la inutilidad de ese género de ascesis, acepta una ofrenda de arroz y la come. Indignados por semejante prueba de debilidad, lo abandonan sus discípulos. Sentándose bajo una higuera, decide no moverse de allí hasta no haber recibido el Despertar. Sufre el asalto de Mara, que compagina en sí la Muerte y el Maligno. Al amanecer de ese mismo día, vencida la tentación, se convierte en el "buddha" (el que ha despertado), conocedor de las Cuatro Nobles Verdades, las cuales predica en Benarés a los discípulos que antes lo habían repudiado. Contaba entonces con 35 años de edad.

Luego de este primer sermón, la comunidad de convertidos se multiplica espectacularmente con la adhesión de brahamanes, reyes y ascetas. A lo largo de su existencia, Buda enfrentó grandes querellas y sinsabores, entre ellos con su sobrino Devadatta, quien había intentado matarlo. Aparentemente, Buda murió a la edad de 80 años, como consecuencia de una indigestión.

El Buda hace derivar todo proceso cósmico de la ignorancia y toda salvación de la cesación de la ignorancia:

La ignorancia produce información innata; la información innata produce la conciencia; la conciencia produce los nombres y las formas; los nombres y las formas producen los seis órganos de sentidos; los seis órganos producen el contacto; el contacto produce la sensación; la sensación produce el deseo; el deseo produce el apego; el apego produce la existencia; la existencia produce el nacimiento; el nacimiento produce la vejez y la muerte (Samyutta Nikaya 22,90 en Eliade 1992: 69).

Así pues, el remedio contra la vejez y la muerte es la abolición de la ignorancia, que equivale a la adopción de Buda, de su ley (dharma) y su comunidad (samgha). Entre los años 100 y 250 d.C. se desarrolló una nueva forma de budismo que estaba conciente de construir un medio de liberación superior a las doctrinas del pasado. Por ese motivo se calificó a sí mismo de Mahayana ("Gran Vehículo”), en contraposición del budismo anterior, que recibió el título de Hinayana ("Pequeño Vehículo"). 
Según el budismo Mahayana (escuela Yogacara), el Buda, como ser trascendente, puede multiplicarse indefinidamente para la salvación de los hombres, en diversas épocas o en el mismo momento histórico. Además del cuerpo absoluto (dharmakaya), el Mahayana le atribuye un cuerpo etéreo (sambhogakaya: cuerpo de disfrute, literalmente), en el cual Buda disfruta o goza de sus méritos religiosos en el paraíso llamado Tierra Pura, y, finalmente, un cuerpo mágico (nirmanakaya), en que se encarna para salvar a los seres humanos.

El dharma vendría a ser el corpus de las enseñanzas y prácticas del budismo. Primeramente, hablemos de las Cuatro Nobles Verdades:

a. La verdad del sufrimiento: Buda descubre que la solución del problema del sufrimiento comienza con el reconocimiento de que la vida es en sí misma un sufrimiento. Esta es la primera de las Cuatro Nobles Verdades. Si la gente examina sus propias experiencias observará que la vida está colmada de sufrimiento, que puede ser físico o mental. Lo cierto es que el sufrimiento del nacimiento, de la vejez, de la enfermedad y de la muerte es inevitable. Empero, cuando Buda afirmó lo inevitable del dolor, no negaba con esto que existía la felicidad de una amistad, la felicidad en el seno familiar y demás. Sin embargo, este tipo de formas no son duraderas, son efímeras, pero la pérdida del vínculo afectivo con el ser querido genera dolor.

b. Causas del sufrimiento: las causas directas del sufrir son el deseo o anhelo y la ignorancia. Esta sería la Segunda Noble Verdad. El anhelo es un deseo profundo que todos los seres vivientes tienen por los placeres de los sentidos y por la vida en sí. Cuando se disfruta de una comida, buena compañía y música adecuada, experimentamos un placer fútil, pues una vez concluida la consumación del placer, no hay satisfacción plena. Por ello, nos gustaría gozar de los placeres una y otra vez, en una interminable cadena de prácticas insulsas. La ignorancia, por su parte, es la inhabilidad de ver la verdad de las cosas, la incapacidad de observar las cosas tal como son. Hay innumerables verdades sobre el mundo que la gente ignora a causa de la limitación en su entendimiento. Una vez desarrolladas nuestras mentes y adquiridas la sabiduría, el pensamiento y la meditación, veremos la Verdad, entenderemos el sufrimiento y su permanencia en la existencia, la ley de causa y efecto y las Cuatro Nobles Verdades. Aboliendo el anhelo y la ignorancia, obtendremos felicidad y "despertar" (iluminación) como lo hiciera el Buda hace alrededor de 2.500 años atrás.

c. El fin del sufrimiento: esta es la gran meta de los enseñanzas de Buda y para lograrla hay que vencer el anhelo, la enfermedad y la ignorancia. Esta es la tercera de las Cuatro Nobles Verdades. Buda pensó que el fin del sufrimiento es la suprema felicidad, la carencia de perturbación, paz absoluta (nirvana).

d. El principal camino para el fin del sufrimiento: señala una vía de ocho pasos que conduce a la extinción del dolor o al centro de la espiritualidad. Es una fórmula sencilla de seguir para obtener la liberación:

i. El correcto entendimiento: es el conocimiento de las Cuatro Nobles Verdades, en otras palabras, el entendimiento de sí mismo (cfr. con la frase atribuida a Sócrates: "Conócete a ti mismo"). Recuérdese que el budismo se basa en el conocimiento, no en la creencia razonable. 
ii. Los pensamientos correctos: tienden a la purificación de la mente y consisten en el pensamiento de renunciación, el pensamiento positivo y el pensamiento inocente.

iii. La palabra correcta: refrena la falsedad, la frivolidad, la hipocresía, la calumnia, la habladuría.

iv. La correcta acción: ayuda a desarrollar el carácter que debe estar autocontrolado y, asimismo, debe tomar en cuenta los derechos de los demás, al evitar el asesinato, el robo y la lascivia.

v. El correcto sustento o medio de existencia: existen cinco oficios que deben ser eludidos. Son éstos: comerciar con armas mortales, comerciar con animales para sacrificio, comerciar con esclavos, comerciar con tóxicos y comerciar con venenos. El modo correcto de ganar la subsistencia significa hacerlo de manera que no sea nocivo o dañino para los demás.

vi. El correcto esfuerzo: consta de cuatro ramas, llamadas esfuerzo para descartar el mal, esfuerzo para prevenir la presentación del mal, esfuerzo para desarrollar el bien y esfuerzo para promover el bien.

vii. La correcta atención: se centra en cuatro áreas, que son atención en cuanto al cuerpo, en cuanto al sentimiento, en cuanto a la mente y en cuanto a los objetos mentales. viii. La correcta meditación: implica un proceso gradual de entendimiento de la mente para concentrarse en un solo objeto, para que la mente permanezca fija en el objeto sin vacilaciones. La constante práctica de la meditación ayuda al sujeto a desarrollar la calma y la relajación y, además, lo prepara para la adquisición de sabiduría y "despertar" (iluminación).

En el Islam, Mahoma (“el alabado" o "digno de alabanza") es el fundador de la religión musulmana. Supónese que nació en La Meca el 10 de noviembre del 570 d.C. Su verdadero nombre era Abul'l-Kasim Mohammed ibn Adb Allah y procedía de la tribu de los Qurays. Así como en el caso de Cristo y Buda, su nacimiento ocurrió en medio de revelaciones que anunciaban la llegada de un gran hombre: su madre no padeció dolores de parto y el cielo se pobló de visones gloriosas. Habiendo perdido a sus padres a una edad temprana, Mahoma quedó al cuidado de su tío, con quien recorrió por primera vez los caminos de la caravanas de los comerciantes. A los 25 años de edad se casó con Jadichah (Kadidja), viuda de 40 años que había heredado una cuantiosa fortuna. Mahoma se dedicó al comercio y cerca de los 40 años decidió permanecer en las cuevas, a semejanza de los ermitaños cristianos, quienes se alejaban de la sociedad para vivir en el ayuno, la meditación y la plegaria. En estos andares, sus visiones lo convirtieron en profeta de Alá, que le ordenó predicar la doctrina del único dios. Dícese que tuvo la visita, en sueños, del ángel Gabriel. Tuvo la confianza de su esposa, de sus familiares, de sus amigos y de la gente humilde, pero hubo quienes se burlaron de las revelaciones de las que hablaba. Su mujer murió algún tiempo después y él se casó en segundas nupcias con una joven llamada Ayesha. Al cabo de diez años, la fortuna de Mahoma se vio desfavorecida por constantes reveses y llegó el momento en que pensó abandonar la misión, pero sus discípulos le refrendaron su confianza y siguió adelante. Persiguió y torturó a los idólatras, lo que alzó a sus enemigos en su contra y huyó a Medina al Nabí, donde fue jefe de una numerosa congregación. La huída de La Meca a Medina sería denominada más adelante por los musulmanes la Hégira y esa fecha, 22 de setiembre del 622, según el calendario cristiano, 
se convirtió en el año 1 de la cronología árabe-islámica. Mahoma construyó el templo llamado "Masdjid" e integró con sus seguidores un verdadero ejército de creyentes y diestros en las armas. Como la persecución contra él y los suyos no terminaba, empezó a predicar la Guerra Santa con el apoyo del islamismo, que creía que Mahoma, llamado el último profeta, había sido enviado con el poder de las armas. Cuando logró conquistar La Meca, en el 630, fue posible que sus pobladores abrazaran la fe musulmana, lo mismo que las tribus árabes de los alrededores. Al año siguiente, Mahoma regresó a la ciudad al frente de 90.000 hombres para celebrar la primera gran peregrinación. Estableció los ritos, determinó las reglas, los cinco rezos diarios, el ayuno durante el Ramadán y convirtió en deber de todo creyente la participación en la Guerra Santa. Pocos meses antes de morir, el 8 de junio del año 632, Mahoma celebró la "peregrinación del adiós" que marcaría el inicio de la tradicional peregrinación hacia La Meca, que es deber fundamental del islamismo.

El Corán (Quran) es para los musulmanes la palabra de Dios, transmitida por el ángel Gabriel al profeta Mahoma. El libro consta de 114 capítulos, llamados surahs, cada uno con un número variable de versos (ayats). Cada surah lleva un título y todos, salvo uno, empiezan con el versículo nominado Basmallah: "En nombre de Dios, el clemente, el misericordioso". Varios capítulos están señalados con letras simbólicas, que tal vez indiquen la colección a la que habían pertenecido anteriormente. Los dos grandes tópicos del Corán son el monoteísmo y el poder de Dios, la naturaleza y el destino de los hombres en relación con la divinidad suprema, que es el único creador del universo, de los hombres y de los espíritus, al reconocer que Dios es justo y benévolo. Los seres humanos son esclavos privilegiados del Señor y tienen la posibilidad de ignorar los mandamientos divinos, a causa de la tentación inducidas por el ángel caído Iblis (Satán), expulsado del cielo por haberse negado a adorar a Adán (Corán 2, 32-33). En el día del juicio, todos los muertos resucitarán, serán pesados y enviados al infierno o al paraíso, según sea el caso, para toda la eternidad. Contiene, también, reinterpretaciones de los relatos bíblicos, numerosas exhortaciones morales, tradiciones sobre la vida del profeta y la base de la islámica (shari'ah).

Se considera que Mahoma nace con el propósito de sacar a su pueblo de un profundo caos abismal de oscuridad: infanticidio, libertinaje, embriaguez. Todas las formas de maldad eran glorificadas y Mahoma es el único capaz de salvarnos, ya que de él se obtiene la paz y del seguimiento de las directrices complicadas en el Sagrado Corán, redactado en el nombre de Allah, el grandioso y misericordioso:

\footnotetext{
Hay algo de noble y heroico en este viaje de Mahoma a Taif; un hombre solitario, desdeñado y rechazado por su propio pueblo, se dirige audazmente hacia adelante, en nombre de Dios, y llama a la ciudad idólatra para que se arrepienta y apoye su misión. Esto derrama una poderosa luz en su creencia acerca del origen divino de su llamado (Muir 1983: 109) (La traducción es nuestra).
}

Las enseñanzas de Mahoma, en forma de Corán, otorgan y trazan los principios y mecanismos para la declaración de la paz y, así, eliminar la guerra y la hostilidad. Dice, por ejemplo, que si dos partes están en disputa, la paz debe ser hecha entre ellas y el diferendo debe ser asentado amigablemente. El Sagrado Corán se constituye en la única solución para la instauración de la paz en el mundo. Como profeta dador de leyes, Mahoma fue mencionado veladamente en el Libro del Deuteronomio $(18,18)$. La más grande enseñanza está delante del mundo: la aceptación de la unicidad de Dios y su regencia en el universo: 
¡En el nombre de Alá, el Compasivo, el Misericordioso! Alabado sea Alá, Señor del Universo, el Compasivo, el Misericordioso, Dueño del día del Juicio, a ti sólo te servimos y a ti sólo imploramos ayuda. Dirígenos por la vía recta, la vía de los que Tú has agraciado, no de los que han incurrido en la ira, ni de los extraviados (Corán 1, 1-7).

En cuanto a la labor soteriológica, el Corán nos dice:

Luego, salvaremos a Nuestros enviados y a los que hayan creído. Salvar a los creyentes es deber Nuestro $(10,103)$.

Alá salvará a quienes Le hayan temido, librándoles del castigo: no sufrirán mal ni estarán tristes $(39,61)$.

\section{Mitos escatológicos}

Estos mitos relatan el final de los tiempos, el momento postrero del mundo y la humanidad. Implica el tránsito de los estadios (edades o eras): caos-paraíso terrenal-caos-restitución del estado edénico. Pues, en algunos casos, no es un fin radical, sino que va seguido de una humanidad nueva y de una reconstrucción. Empero, supónese generalmente la destrucción del universo por medio de cataclismos de proporciones cósmicas: temblores, incendios, derrumbamientos de montañas, epidemias devastadoras.

En la India, en los pralaya (relatos del fin del mundo), se desarrolló la doctrina de los cuatro yugas, las cuatro edades del mundo. Lo esencial de esta teoría es la creación y destrucción cíclicas y la creencia en la perfección en los comienzos. La unidad de medida más pequeña es el yuga, la "edad”. Un yuga va precedido y seguido por una aurora y un crepúsculo que entrelazan las edades entre sí. Un ciclo completo o mahayuga, se compone de cuatro edades de duración desigual, de las cuales la más larga aparece al principio del ciclo y la más corta al final. Así la primera "edad", la krita-yuga, dura 4.000 años de aurora a crepúsculo; le siguen treta-yuga de 4.000 años, dvarapa-yuga de 2.000 años y kali-yuga de 2.000 años. Por consiguiente, un mahayuga dura 12.000 años. Luego de las disminuciones progresivas de la duración de cada nuevo yuga, corresponde, en el plano humano, una disminución de la duración de la vida, acompañada de un relajamiento de las costumbres y de una declinación de la inteligencia. El paso de un yuga a otro se marca por el crepúsculo (decrecendo interior), lo cual implica la reinserción a las tinieblas primordiales. El último yuga, en el que nos encontramos actualmente, se llama "edad de las tinieblas" (kali-yuga). El ciclo concluye con una disolución: nacimiento-desgaste-destrucción. Cada "año" de los que venimos hablando es igual a 360 años, por tanto el Mahayuga de 12.000 años corresponde a 4.320 .000 años, como los entendemos en la actualidad. El fin llegará cuando el horizonte se inflame, siete o doce soles aparecerán en el cielo, se secarán los mares y se quemará la tierra. El fuego Samvartaka (fuego del incendio cósmico) destruirá el universo completo. Luego caerá una lluvia diluvial durante doce años, la tierra quedará sumergida y la humanidad anulada. Sin embargo, para la India no hay un fin radical en el mundo, hay intervalos más o menos largos entre el aniquilamiento de un universo y la aparición del otro. 
La destrucción final del mundo y la regeneración de dioses y hombres de los nórdicos se llama Ragnarok, crepúsculo de los dioses (de ragna-regin: dioses y rockr: oscuridad). El viaje a través de la vida ha sido largo, pero aún no hemos alcanzado el fin, que es el principio también. Cuando se acaba la vida, se produce un cambio: surge un nuevo día y un sol sin sombras. El germen de la muerte se hallaba en la naturaleza desde el origen y éste va desarrollándose gradualmente, o sea, acontece un debilitamiento de la fuerza de los dioses y de los hombres. La disolución está precedida del desorden de la vida:

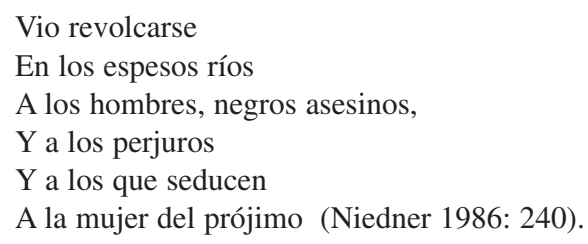

La depravación y la lucha en el mundo proclaman la cercanía del Ragnarok. Previamente, habrá un invierno llamado Fimbul, durante el cual la nieve caerá por los cuatro costados del mundo. Habrá tres inviernos seguidos, en los cuales la guerra y la discordia se extenderán por toda la tierra. Los hermanos se matarán entre sí para conseguir mayores ganancias y nadie se salvará, ni sus padres ni sus hijos. Los Edda dicen:

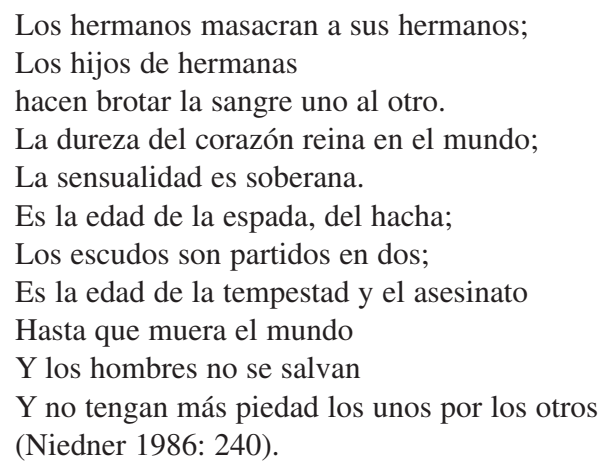

El lobo Fenris, habiéndose escapado de sus ligaduras, devorará el sol y el otro lobo, Moongarm, devorará la luna; esto producirá grandes daños; entonces las estrellas serán precipitadas del cielo, la tierra será sacudida tan violentamente que los árboles serán arrancados de raíz, los fundamentos de las montañas serán estremecidos y todas las cadenas saltarán en pedazos. El mar se precipitará sobre la tierra a causa de la serpiente Midgard: habrá de retorcerse con rabia gigantesca y alcanzará la tierra. Sobre las aguas flotará el navío Nagifar, el barco de los clavos, que está construido con los clavos de los hombres muertos. Por esto, según la mitología nórdica, se debía tener cuidado en morir con un número par de clavos, de lo contrario proporcionaría materiales para la construcción del barco en cuestión.

La mandíbula inferior del lobo Fenris llega hasta la tierra y la superior al cielo, el fuego brota de sus ojos y de sus narices. La serpiente Midgard, colocada al lado de Fenris, vomita ríos de veneno que invaden el aire y la aguas. En medio de tal devastación, los cielos se parten y los hijos de Muspel cabalgan por la abertura sobre un rayo. Surt cabalga primero, delante y detrás 
de sí arde un fuego abrasador. Su espada es más brillante que el mismo sol. Bifrost (el arco iris) se quiebra bajo sus pasos. Se dirigen hacia el campo de batalla (Vigrid), junto con el lobo Fenris, la serpiente Midgard y Loke con todos los compañeros de Hel, Hrym y los gigantes del frío.

Heimdal se levanta y sopla con todas sus fuerzas el cuerno Gjallar para despertar a los dioses, que se reúnen rápidamente. Odín cabalga hasta la fuente de Mimer y le pregunta cómo debe comenzar la acción guerrera. Los dioses y todos los einherjes de Vahal se dirigen al campo de batalla encabezados por Odín, quien se coloca frente al lobo Fenris. Thor combate con la serpiente Midgard, a quien logra matar, mas cae muerto, ahogado por los ríos de veneno que fluyen del cuerpo de la sierpe monstruosa. Frey se enfrenta con Surt. El lobo devora a Odín, aunque Vidar trata de rescatarlo con la ayuda de unos zapatos especiales. Loke y Heimdal combaten y se matan entre ellos. Surt lanza fuego y llamas sobre el mundo, las más altas jamás vistas.

El conflicto final es inevitable, incluso pese a que Odín muere en él, pues es el último combate entre los que han gobernado y bendecido el cielo y la tierra y los eternos enemigos, los poderes oscuros que existían antes de que el universo fuese creado. Impera una ley de destructividad y corrupción: todas las cosas poseen una fuerza inherente que las lleva a la ruina, un germen de muerte. En la lucha, las fuerzas antagónicas combaten y se destruyen recíprocamente. El Ragnarok es el desencadenamiento de todos los poderes del caos. El fuego, el agua, las tinieblas y la muerte trabajan juntos para destruir el mundo. Empero, la tierra se regenera; en el incendio producido por Surt, una mujer llamada Lif (vida) y un hombre de nombre Lifthraser se ocultarán en el bosque de Hodminer. El rocío les servirá de alimento y darán vida a una raza numerosa. Habrá un día del juicio final, cuando los bondadosos y los perversos serán separados. El dios regente, padre de todos, que existía desde antes del tiempo, entrará en su reino eterno.

En Irán, se creía que una conflagración universal (ekpyrosis) pondrá fin a toda la historia y será el momento del juicio de esta. Los individuos habrán de responder por lo realizado en "la historia" y sólo los que no sean culpables conocerán la beatitud y la eternidad. Para los mazdeístas, el mundo fue creado por Dios en seis días y en el sétimo descansó. Su universo tendrá una duración de seis eones, en los cuales el mal vencerá y triunfará en el mundo. Durante el curso del sétimo milenio, el príncipe de los demonios será encadenado y la humanidad vivirá mil años de reposo y de justicia perfecta. Sin embargo, pasado el lapso indicado, el demonio se escapará de sus cadenas y volverá a la guerra contra los justos. Al final será vencido y en el octavo milenio el mundo será recreado para la eternidad.

\section{Mitos heroicos}

Los mitos heroicos cuentan las aventuras y las hazañas de un héroe, un ser mítico que ha vencido incontables vicisitudes, entre las cuales se destacan la lucha contra monstruos, para salvar al poblado o a la damisela en desgracia; la batalla contra las fuerzas de la oscuridad que pretenden subyugar al género humano.

En Grecia, Teseo se destacó por haber vencido al Minotauro y así liberó a Atenas de la tiranía cretense. Primeramente, Poseidón, dios rector de las aguas, le obsequió al rey de Creta a Minos, un hermoso toro blanco. El rey lo conserva con gran estima, ignorando que había 
surgido, en su esposa Pasífae, un antinatural deseo lascivo por el bovino. Sin mayor dilación, Pasífae le ordenó a Dédalo, arquitecto prodigioso, idear un modo viable para que ella pudiese satisfacer sus enfermizos instintos carnales con el toro. Por lo tanto, Dédalo construyó una vaca artificial de madera, la cual estaba hueca, con el objeto de que la reina se introdujera allí y se ayuntara con el animal. Así lo hizo y de este contacto nacería una criatura híbrida: mitad humana y mitad bovina. Se le llamó Minotauro y fue instalado en el célebre laberinto, palacio de intrincados pasadizos, creación magistral de Dédalo. Empero, como el Minotauro se alimentaba de carne humana, Minos exigió un tributo humano anual de siete doncella y siete mancebos. Egeo, rey de Atenas, cumplía sin retardo alguno; no obstante, su hijo Teseo decidió que ya era tiempo de imponerse y terminar de esta manera con la macabra tiranía cretense. Ofrecióse él mismo para ir entre el grupo de rehenes. Llegó a Creta, mas contempló la dificultad de llevar a cabo su misión. Quien entraba al laberinto inexorablemente era alcanzado por el Minotauro y, aún con la mejor de las suertes, no podía salir, pues el laberinto era un rompecabezas de caminos entrelazados. No obstante, con la ayuda de la princesa Ariadna, hija de Minos y Pasífae, Teseo pudo realizar la ejecución del horrendo y repulsivo monstruo y salir del laberinto. El ardid sugerido por la princesa fue la utilización de un simple ovillo de lana: mientras ella lo sostenía en la salida, el héroe ateniense llevaba el hilo de lana amarrado a su cintura. Esa fue su guía para salir del laberinto.

Perseo, por su parte, es un héroe de origen argivo, quien figura entre los antepasados de Heracles (llamado Hércules entre los romanos). Acrisio, su abuelo materno, había consultado el oráculo acerca de si tendría o no descendencia. La respuesta fue que el hijo de su hija Dánae lo destronaría y sería el causante de su muerte. De ahí que Dánae fue instalada y encerrada en una torre, con el fin de no ser visitada jamás por ningún varón. Sin embargo, pese a todas las precauciones, Dánae dio a luz un hijo, concebido por la intervención de Zeus, en forma de lluvia de oro. Acrisio se dio cuenta de la situación y optó por arrojar al mar a su hija y a su nieto, encerrados en un cofre de madera. Los naúfragos fueron recogidos por Dictis, quien los acogió en su hogar y se hizo cargo de la educación del niño. Pasados los años, el rey Polidectes pretendía a Dánae, pero Perseo la cuidaba celosamente. El rey invitó a un banquete a sus amigos, entre ellos al héroe. Todos habían convenido en que el mejor obsequio para el rey era un caballo, mas Perseo respondió que, si era necesario, le traería la cabeza misma de Medusa, una de las Gorgonas. Al día siguiente, todos los invitados llevaron el corcel ofrecido, sólo Perseo llegó con las manos vacías, oportunidad que aprovechó Polidectes: le ordenó traer la cabeza de Medusa so pena de perder a su madre, ya que él la tomaría por esposa a la fuerza.

En esta coyuntura, los dioses Hermes y Atenea acudieron en ayuda de Perseo y le proporcionaron los medios adecuados para cumplir su imprudente promesa. Habiendo seguido el consejo divino, el joven fue al encuentro de las hijas de Forcis (Enio, Pefredo y Dino), conocidas como las Grayas, quienes tenían entre las tres un solo ojo y un solo diente. Apoderóse Perseo del diente y del ojo y se negó a devolverlos mientras no le indicasen el camino hacia la mansión de las Ninfas. Estas eran poseedoras de sandalias aladas, un zurrón llamado kibisis y el casco de Hades, que tenía la facultad de volver invisible a quien lo ostentara. Las Ninfas le entregaron todos estos objetos y Hermes lo armó con una hoz de acero muy incisivo. Perseo se dirigió entonces a la mansión de las Gorgonas, las cuales yacían dormidas. Medusa era un horrible monstruo, cuyo cuello se hallaba protegido por escamas de dragón, tenía cabellera de serpientes y colmillos como de jabalí. Sus manos eran de bronce y poseía alas de 
oro, con las cuales volaba. Además, su mirada era tan poderosa que transformaba en piedra a cuantos veía. Por ello era imposible vencerla sin ayuda divina: Perseo se elevó por los aires gracias a sus sandalias aladas y, mientras Atenea sostenía encima de Medusa un escudo de bronce bruñido a modo de espejo, él decapitó a la Gorgona. Del cuello cercenado de Medusa surgieron un caballo alado (Pegaso) y un gigante (Crisaor). El argivo héroe guardó la cabeza en el zurrón y emprendió el viaje de regreso. Las dos hermanas de Medusa lo persiguieron, pero gracias al casco de Hades, Perseo se volvió invisible.

En el camino, el héroe pasó por Etiopía, donde halló a Andrómeda, atada a una roca, expiando unas palabras imprudentes que había proferido su madre Casiopea. Al ver a la hermosa joven en peligro, Perseo sintió súbito amor por ella y prometió a su padre Cefeo que la liberaría si se la daba por esposa. El trato fue aceptado y Perseo, gracias a las armas mágicas que poseía, pudo matar fácilmente al monstruo marino que iba a devorar a Andrómeda y condujo a la doncella al lado de los suyos. Andrómeda tenía un tío, Fineo, quien quería casarse con ella. Fineo, irritado por la proyectada boda entre ambos, urdió un plan en contra de la nueva pareja. Pero Perseo lo descubrió a tiempo y, al mostrarle la cabeza de Medusa, convirtió a los detractores en estatuas de piedra.

Acompañado de su amada, llegaron de regreso a casa. Perseo se vengó de Polidectes, transformándolo en estatua pétrea. Resuelto este asunto, se dirigieron a Argos, su auténtica patria. Acrisio, abuelo de Perseo, huyó del lugar, hacia el país de los pelasgos, para no dar oportunidad al cumplimiento del oráculo. Sin embargo, el rey de los pelasgos había organizado unos juegos y Perseo se presentó en calidad de participante. Acrisio se apersonó como simple espectador. Al lanzar el disco, el héroe hiere en el pie, accidentalmente, a su abuelo, lo que le causa la súbita muerte. De este modo el funesto oráculo se vio cumplido.

En la cultura moderna de la mass-media, Supermán es un redentor comercializado que viene a llenar un vacío en el deseo colectivo de salvación. Supermán es un ser procedente de otro planeta (Kriptón) y es invulnerable: las balas rebotan en su pecho, dobla las barras de acero sin esfuerzo, salta los enormes rascacielos de la ciudad, corre a una velocidad superior a la de cualquier vehículo, posee poderes inimaginables en su visión. Adopta la identidad secreta de Clark Kent, un tímido reportero de un periódico, para mezclarse con el común de los mortales. No obstante, en los momentos de necesidad cambia sus vestiduras y emerge el héroe que se halla oculto en él. Utiliza sus poderes para el bien, aunque al principio de su saga es perseguido por la policía pues actúa como justiciero fuera de la ley. Educado con sólidos valores morales por una pareja de clase media, Supermán defiende al oprimido, respeta la propiedad privada, ampara a la ciudad de Metrópolis, ayuda a su país adoptivo (Estados Unidos de América), desbanca a los corruptos en la política y mantiene una fuerte lucha interior entre sus dos personalidades, porque se ha enamorado de su colega periodista en el Daily Planet, Lois Lane, quien sólo se fija en el héroe y no en el reportero Clark Kent. A lo largo de los sesenta años de publicación y divulgación de las aventuras del Hombre de Acero acontecen infinidad de sucesos, hasta que, en noviembre de 1992, un villano de nombre Doomsday (día del juicio final) pone fin a la existencia de Supermán en una lucha sin paralelo: el Hombre de Acero ofrenda su vida para salvar a Metrópolis del monstruoso destructor de origen desconocido. Empero, fallece y resucita en el Superman Blue: un ser energético, con un traje de color azul y blanco, sus propios poderes le son aún desconocidos. Debe aprender a utilizar su potencial, lo cual implica el tener un cúmulo de energía conciente capaz de manipular la misma energía. No lleva capa y 
cuando se transforma en Clark Kent, por medio de la concentración y densificación mental, resulta ser vulnerable como cualquier mortal. Supónese que, ante la cantidad de críticas negativas, nació el híbrido del Supermán Rojo con el Supermán Azul, que traerá de vuelta al Supermán original, el de siempre.

Desde la perspectiva de análisis junguiano, las instancias narrativas del mito heroico son expresión absoluta del arquetipo que evidencia la dinámica de la psicoenergía en los diversos estadios del proceso de individuación: la tendencia hacia la obtención del selbst, el sí mismo, el equilibrio psicoenergético. Así pues, el hombre se halla frente a la polaridad de las fuerzas antagónicas: el bien y el mal, por ejemplo. El héroe se instala, mediante su lucha con demonios, monstruos, seres alienígenos, en los estratos más profundos de lo inconsciente. Tal batalla alude hacia la madre, quien simbólicamente manifiesta lo inconsciente. En suma, en la victoria de todo héroe se visualiza el anhelo personal de vencer a la madre, vencer las condiciones personales particulares (histórico-sociales), con el objeto de extraer del hontanar primario de la vida individual los gérmenes autóctonos del hombre como ser cultural. Obviamente, esta tarea es ingente; de ahí que el héroe sea el símbolo de esa imagen divina, cosmogónica y soteriológica, que se encuentra cifrada en todos nosotros y sólo espera ser reconocida y restituida a la vida.

\section{Consideraciones finales}

De toda la taxonomía anteriormente expuesta, podemos concluir que la comosgonía es el soporte de toda la categorización de mitos. Dado que la creación del mundo es la creación por antonomasia de todos los elementos en particular. La cosmogonía constituye el modelo ejemplar de todas las especies de la creación; todo ha tenido un "origen": una planta, un monte, un dios, el hombre, un héroe, un salvador, un final del mundo.

Las cosmogonías traducen un sentimiento universal de trascendencia, es decir, la atribución de los orígenes del universo a uno o varios seres cósmicos. Constituyen un modelo para que la humanidad pueda concebir el despliegue de la energía y esforzarse en consumar sus propios proyectos. Son el modelo paradigmático de toda categoría, porque el cosmos es el arquetipo ideal de toda situación creadora. El cosmos es una obra divina, está santificado en su estructura. Por extensión, todo lo que es perfecto, pleno, armonioso, todo lo que se parece a un cosmos es sagrado. Hacer bien cualquier cosa, obrar, construir, crear, estructurar, dar forma equivale a decir que se introduce algo nuevo a la existencia, que se le da vida y, en última instancia, que se le asemeja al organismo armonioso por excelencia: el cosmos.

Carl Gustav Jung observa que toda cosmogonía implica una cierta noción de sacrificio: dar forma a una materia es particular en la energía primordial para modificarla, lo que no ocurre sin lucha: las cosmogonías están acompañadas de teomaquias, gigantomaquias, estragos inmensos, en los cuales dioses y hombres se desmembran. El orden y la vida no nacen sino del caos y de la muerte. Estos contrarios son parejas gemelas, las dos caras diurna y nocturna. Todo progreso se apoya sobre una destrucción; cambiar es a la vez nacer y morir.

El mundo es el resultado de un combate entre dos principios polares, durante el cual queda destruido el árbol de la vida. Pero de la destrucción y la muerte surge el cosmos y una vida nueva. La nueva creación se origina en la muerte de la divinidad total. La génesis implica 
el fin del caos por la entrada en el universo de la forma, de un orden, de una jerarquía. Pascal decía que el orden basta para caracterizar la invención, la cual es la percepción de un orden nuevo. La obra del creador precede al caos o le sucede. Este no es más que una primera fase: una masa elemental e indiferenciada (tohu-bohu, en alemán) que el espíritu o hálito divino penetra, para darle forma.

\section{Bibliografía}

Aristóteles. 1978. Metafísica. México: Cumbre.

Cabrera, Edgar. 1992. La cosmogonía maya. San José: Liga Maya Internacional.

Campbell, Joseph. 1980. El héroe de las mil caras. México: F.C.E.

1984. Corán. Barcelona: Plaza y Janés.

Diel, Paul. 1991. El simbolismo en la mitología griega. Barcelona: Labor.

Eliade, Mircea. 1983. Mito y realidad. Barcelona: Labor/Punto Omega.

1992. El mito del eterno retorno. Barcelona: Alianza/Emecé.

Eliade, Mircea y Ioan Couliano. 1992. Diccionario de las religiones. Barcelona: Paidós.

Ferreto, Adela. 1982. Historias del Buen Sibú y de los bribris. San José: Ed. Universidad Estatal a Distancia.

Fulcanelli. 1991. El misterio de las catedrales. Barcelona: Plaza y Janés.

Gómez Pérez, Rafael. 1986. Los dioses griegos. Madrid: Rialp.

Graves, Robert. 1989. Los mitos griegos. México: Alianza.

Grimal, Pierre. 1984. Diccionario de mitología griega y romana. Barcelona: Paidós.

Krickeberg, Walter. 1988. Mitos y leyendas de los aztecas, incas, mayas y muiscas. México: F.C.E.

Loisy, Alfred. 1967. Los misterios paganos y el misterio cristiano. Buenos Aires: Paidós.

Mondolfo, Rodolfo. 1983. El pensamiento antiguo. Buenos Aires: Losada.

Muir, William. 1983. Life of Mohamet. New York: Colophon Books. 
Niedner, Heinrich. 1986. Mitología nórdica. Barcelona: Edicomunicación.

Píndaro. 1981. Odas y fragmentos. México: Porrúa.

Platón. 1978. Metafísica. México: Cumbre.

1979. Popol Vuh. San José: EDUCA.

1957. Sagrada Biblia. Nueva York: Grolier

Uriza, Francisco. 1991. "La simbólica de la francmasonería”. Symbolos: arte , cultura, gnosis. Invierno 1990-Verano 1991: 89-109. 